\title{
Energy efficiency in mass-built housing and demonstrative bioclimatic models in a hot-dry climate zone
}

\section{Eficiencia energética en vivienda de construcción en serie y en modelos demostrativos bioclimáticos en zona de clima cálido seco}

ROMERO-MORENO, Ramona†*, BOJÓRQUEZ-MORALES, Gonzalo, LUNA-LEÓN, Aníbal and REYES-BARAJAS, Karmina

Universidad Autónoma de Baja California, Faculty of Architecture and Design, Master's and Doctoral Program in Architecture, Urbanism and Design, Mexico.

ID $1^{\text {st }}$ Author: Ramona, Romero-Moreno / ORC ID: 0000-0002-5853-0229, Research ID Thomson: F-4992-2818, CVU CONACYT ID: 122232, SNI CONACYT ID: 33982

ID $1^{\text {st }}$ Coauthor: Gonzalo, Bojórquez-Morales / ORC ID: 0000-0001-9303-9278, Researcher ID Thomson: C-8687-2018, CVU CONACYT ID: 79645, SNI CONACYT ID: 45005

ID $2^{\text {nd }}$ Coauthor: Aníbal, Luna-León / ORC ID: 0000-0003-3480-0607, Researcher ID Thomson: AAY-2003-2020, CVU CONACYT ID: 79641

ID $3^{\text {rd }}$ Coauthor: Karmina, Reyes-Barajas / ORC ID: 0000-0003-2255-8139, Researcher ID Thomson: AAP-1246-2020, CVU CONACYT ID: 987077

DOI: $10.35429 / J A D .2020 .11 .4 .1 .8$

Received January 10, 2020; Accepted June 30, 2020

\begin{abstract}
The residential sector is one of the biggest consumers of electric energy, especially in zones with extreme dry-hot climates such as Mexicali. The implementation of NOM-020 ENER-2011 energy efficiency standards for the envelope of the dwelling is essential to provide thermal comfort with a lower energy consumption. The goal of this article is to evaluate the application of energy efficiency standards in three housing models: The first one was a prototype of mass-built housing (commercial model) and the remaining were demonstrative dwelling prototypes built with bioclimatic criteria. The analysis was made with the digital calculation tools provided by the Secretary of Energy and the National Commission for the Efficient Use of Energy. The results showed that for the commercial dwelling to reach the energy efficiency standards, it is required to diminish the overall heat transfer coefficient Therefore, it was achievable to improve the energetic efficiency by including the bioclimatic housing criteria. Although important efforts have been made to optimize the housing design, they have not been effective enough to improve the energy efficiency of the mass-built housing
\end{abstract}

Energy efficiency standards, Mass-built housing, Hot-dry climate

\begin{abstract}
Resumen
El sector residencial es uno de los mayores consumidores de energía eléctrica sobre todo en zonas de clima cálido seco extremoso como Mexicali. La implementación de normas de eficiencia energética para la envolvente de la vivienda NOM020-ENER-2011 es indispensable para generar condiciones de confort térmico con un menor consumo de energía. El objetivo del artículo fue evaluar la aplicación de las normas de eficiencia energética en tres modelos de vivienda: el primero fue un prototipo de vivienda de construcción en serie (modelo comercial) y los restantes, fueron prototipos demostrativos de vivienda construida con criterios bioclimáticos El análisis fue realizado con la herramienta de cálculo digital proporcionada por la Secretaria de Energía y la Comisión Nacional para el Uso Eficiente de la Energía. Los resultados mostraron que para que la vivienda comercial cumpla con los estándares de eficiencia energética requiere disminuir el coeficiente global de transferencia de calor. Se observó que fue factible mejorar la eficiencia energética al incluir criterios de los modelos bioclimáticos de vivienda. Aunque se han hecho esfuerzos importantes, para optimizar el diseño de la vivienda, no han resultado lo suficientemente efectivos para mejorar la eficiencia energética de la vivienda de construcción en serie.
\end{abstract}

Normas de eficiencia energética, Vivienda de construcción en serie, Clima cálido seco

Citation: ROMERO-MORENO, Ramona, BOJÓRQUEZ-MORALES, Gonzalo, LUNA-LEÓN, Aníbal and REYESBARAJAS, Karmina. Energy efficiency in mass-built housing and demonstrative bioclimatic models in a hot-dry climate zone. Journal Architecture and Design. 2020. 4-11:1-8.

\footnotetext{
* Correspondence to Author (Email: ramonaromero@uabc.edu.mx)

$\dagger$ Researcher contributing as first author.
} 


\section{Introduction}

Energy efficiency in the residential sector is part of the policies to cushion the impact of climate change and its impact on electricity consumption. The residential sector is one of the main consumers of electricity. Globally, this sector is responsible for $22 \%$ of total consumption and $19 \%$ of $\mathrm{CO}_{2}$ emissions (Global Alliance for Buildings and Construction, et al., 2019). In Mexico, in 2016, the electricity consumption of the residential sector represented $26.8 \%$ of the total electricity consumption (Secretaria de Energía, 2017). In areas with an extreme hot climate, such as Mexicali, electricity consumption in the residential sector represents $43.9 \%$ of total consumption (National Institute of Statistics and Geography, 2016). In hot areas, electricity consumption is increased by the use of environmental conditioning systems to maintain conditions of thermal comfort in the hot season.

The housing envelope is the filter of the impact of weather conditions; greater energy efficiency of the same implies greater savings in the use of energy. Laws, codes, regulations and / or standards have been developed in different countries to improve the energy efficiency of buildings and in particular the residential sector. In Spain, there is the Technical Code for Buildings which contains regulations for energy saving (Ministerio de Fomento, 2019). In the United States there are various energy efficiency codes and standards, such as the California Energy Code (California Building Standards Commission, 2019) and the ASHRAE 90.2 standard for the energy efficient design of low-rise residential buildings (American Society of Heating, Refrigeration and Air Conditioning Engineers, 2018), among others.

In Mexico, the public policy to promote energy efficiency in buildings is regulated for non-residential buildings in NOM-008-ENER2001 (Official Gazette of the Federation DOF, 2001) and the official standard for the envelope of buildings for residential use by NOM-020ENER-2011 (NOM-020) (DOF, 2011). In this sense, both standards seek to optimize the design of the enclosure, from the point of view of thermal and energy performance.
Obtaining as benefits, among others, energy savings due to the reduction of the capacity of the cooling equipment, since the generalized use of these equipment affects the peak demand of the national electricity system. The building envelope becomes an element of interaction between the exterior and interior environment of the house. With this, there may be envelopes that favor the increase or decrease of the heat gain to the interior, and with this the impact on the conditions of thermal comfort, especially in areas of hot dry climate.

\section{Energy efficiency standards for housing in Mexico}

NOM-020 becomes the instrument to determine the energy efficiency of buildings for residential use, applies to new homes or extensions, came into force in 2011, although it is not mandatory; the houses can be of the isolated single-family type (one house per lot) or collective (condominium, multi-family).

NOM-020 is focused on the analysis of the envelope (ceilings, walls, windows and doors). Basically, it estimates the heat gains by conduction and radiation through the envelope, from the comparison of a reference home (VR) and the projected home (VP) - proposal that is evaluated. The characteristics of the VP are defined in the executive project or in the built house, as the case may be; the main requirements are: construction areas and systems by orientation of walls and ceilings, as well as the characteristics and areas of windows and doors by orientation. Regarding VR, it maintains a relationship with VP in areas and orientation, based on considering $90 \%$ opaque part in walls and $10 \%$ transparent part and in ceilings with $100 \%$ opaque part.

In both cases (VP and VR), it is required to have the thermophysical properties of the materials, to estimate the global heat transfer coefficient of the different construction systems of walls and ceilings; the equivalent temperature values for heavy walls, light walls and windows by orientation (north, east, south and west); Average solar gain factors for windows based on their orientation and for skylights and domes. 
With the above, an "energy budget" is obtained that seeks to limit the heat gain of the $\mathrm{PV}$. If the PV has a heat gain equal to or less than the VR, this means that the projected home passes compliance with the standard and shows the corresponding energy savings (DOF, 2011).

The version of NOM-020 published in 2011 was modified in 2016 (DOF, 2016), since it was not possible to comply with it, with the common construction systems for serial construction housing. Adjustments were made to the global heat transfer coefficients, equivalent temperature and solar radiation gain; the values are regionalized by state and cities of the country. Table 1 shows those corresponding to the city of Mexicali, Baja California.

\begin{tabular}{|c|c|c|c|c|c|}
\hline \multicolumn{6}{|c|}{ Global heat transfer coefficient $\left(\mathrm{W} / \mathrm{m}^{2{ }^{\circ} \mathrm{C}}\right)$} \\
\hline \multirow[t]{3}{*}{ Levels } & $\begin{array}{l}\text { Up to three } \\
\text { levels }\end{array}$ & $\begin{array}{l}\text { Walls and } \\
\text { ceilings }\end{array}$ & & \multicolumn{2}{|c|}{0.625} \\
\hline & \multirow{2}{*}{$\begin{array}{l}\text { More than } \\
\text { three levels }\end{array}$} & Ceiling & & \multicolumn{2}{|c|}{0.625} \\
\hline & & Wall & & \multicolumn{2}{|c|}{0.714} \\
\hline \multicolumn{6}{|c|}{ Equivalent temperature $\left({ }^{\circ} \mathrm{C}\right)$} \\
\hline \multirow[t]{9}{*}{ Driving } & Inside & 25 & & & \\
\hline & $\begin{array}{l}\text { Bottom } \\
\text { surface }\end{array}$ & 34 & & & \\
\hline & Ceiling & 50 & & & \\
\hline & & \multicolumn{4}{|c|}{ Orientation } \\
\hline & Walls & $\mathrm{N}$ & $\mathrm{S}$ & $\mathrm{E}$ & $\mathrm{O}$ \\
\hline & Massive & 36 & 40 & 37 & 39 \\
\hline & Light & 41 & 45 & 43 & 46 \\
\hline & Window & 30 & 32 & 32 & 33 \\
\hline & Skylights & \multicolumn{4}{|c|}{29} \\
\hline \multicolumn{6}{|c|}{ Solar gain coefficient $\left(\mathrm{W} / \mathrm{m}^{2}\right)$} \\
\hline \multirow[t]{2}{*}{ Radiation } & Window & 70 & 159 & 131 & 165 \\
\hline & Skylights & \multicolumn{4}{|r|}{322} \\
\hline
\end{tabular}

Table 1 Global heat transfer coefficient, average equivalent temperature and solar gain factor., NOM-020ENER-2011, Mexicali, Baja California

Source: Elaboration based on DOF, 2016

Therefore, the objective of this article is to determine the impact of the application of energy efficiency standards NOM-020 in series construction housing in a context of hot dry climate, such as Mexicali; with the purpose of knowing to what extent they comply with energy efficiency regulations or if modifications are required to existing construction systems; and includes the proposal of two demonstration models of housing designed with bioclimatic criteria

The article consists of three parts. In the first, the introductory section is shown and the main guidelines of NOM-020 are specified. In the second, about the method, the case studies, the criteria used, and the evaluation tool are described.
In the third, the results of the application of NOM-020 in the different case studies, the requirements for compliance with it, and the conclusions are presented.

\section{Methodology}

Serial construction housing for low-income families, called affordable housing, was evaluated; Three housing models were used: one was the commercial housing model (MC) and two were bioclimatic housing models (BM1 and BM2), these are demonstrative housing prototypes, products of the research project "Thermal comfort and energy saving in economic housing in Mexico: regions with a hot, dry and humid climate "(Universidad Autónoma de Baja California, et al, 2013). The case studies have the main facade to the north, one of the side facades is built at the property limit, they have a corridor that connects the front with the rear of each house. The dimensions of each lot are $6.86 \times 17.50 \mathrm{~m}$, with a surface area of $120 \mathrm{~m}^{2}$. The homes have a common space (living room-kitchen), one or two bedrooms and a bathroom (Figure 1 and 2).

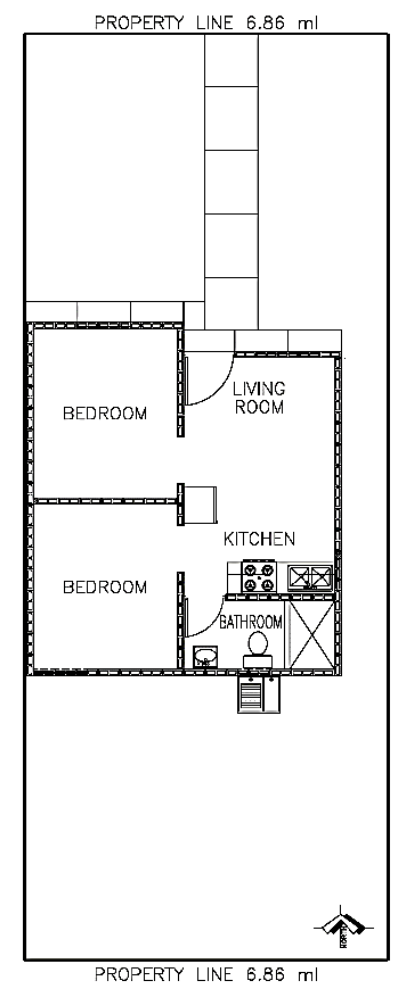

Figure 1 Architectural plan, Commercial model (MC), Fracc. Places of Puebla, Mexicali Source: Own elaboration, AutoCad 




Figure 2 Architectural plan, Bioclimatic Models BM1 and BM2, Fracc. Places of Puebla, Mexicali Source: Own elaboration, AutoCad

The MC and BM1 models have a surface area of $38 \mathrm{~m}^{2}$ and the BM2, $43.8 \mathrm{~m}^{2}$. Table 2 shows the wall and ceiling surfaces of each of the housing models.

\begin{tabular}{|c|c|c|c|c|c|}
\hline \multirow{2}{*}{\multicolumn{2}{|c|}{ Surfaces }} & \multicolumn{4}{|c|}{ Areas $\left(\mathbf{m}^{2}\right)$} \\
\hline & & $\begin{array}{l}\text { Walls } \\
\text { (opaque) }\end{array}$ & $\begin{array}{l}\text { Sale- } \\
\text { Nas }\end{array}$ & $\begin{array}{l}\text { Doors } \\
\text { (opaque) }\end{array}$ & Total \\
\hline \multicolumn{6}{|c|}{ Business model (MC) } \\
\hline \multirow[t]{4}{*}{ Vertical } & $\mathrm{N}$ & 14.03 & 2.08 & 1.92 & 18.03 \\
\hline & S & 16.77 & 1.24 & - & 18.01 \\
\hline & $\mathrm{E}$ & 19.19 & 0.61 & - & 19.80 \\
\hline & $\mathrm{O}$ & 19.78 & - & - & 19.78 \\
\hline \multirow[t]{2}{*}{ Horizontal } & $\mathrm{T}$ & & & & 38.00 \\
\hline & $\mathrm{P}$ & & & & 38.00 \\
\hline \multicolumn{6}{|c|}{ Bioclimatic model (MB1) } \\
\hline \multirow[t]{4}{*}{ Vertical } & $\mathrm{N}$ & 15.28 & 2.14 & - & 17.41 \\
\hline & $\mathrm{S}$ & 13.18 & 1.37 & 1.81 & 16.34 \\
\hline & $\mathrm{E}$ & 23.09 & 2.58 & 2.18 & 27.85 \\
\hline & $\mathrm{O}$ & 27.22 & - & - & 27.22 \\
\hline \multirow[t]{2}{*}{ Hori } & $\mathrm{T}$ & & & & 38.00 \\
\hline & $\mathrm{P}$ & & & & 38.00 \\
\hline \multicolumn{6}{|c|}{ Bioclimatic model (BM2) } \\
\hline \multirow[t]{4}{*}{ Vertical } & $\mathrm{N}$ & 18.70 & 2.49 & 2.15 & 23.34 \\
\hline & $\mathrm{S}$ & 18.77 & 2.81 & - & 21.58 \\
\hline & $E$ & 20.54 & - & - & 20.54 \\
\hline & $\mathrm{O}$ & 28.24 & 1.31 & 2.15 & 31.70 \\
\hline \multirow[t]{2}{*}{$\mathrm{H}$} & $\mathrm{T}$ & & & & 43.80 \\
\hline & $\mathrm{P}$ & & & & 43.80 \\
\hline \multicolumn{6}{|c|}{$\begin{array}{l}\text { Symbology: } \mathrm{N}=\text { north, } \mathrm{S}=\text { south, } \mathrm{E}=\text { east, } \mathrm{O}=\text { west, } \mathrm{H}= \\
\text { horizontal, } \mathrm{T}=\text { ceiling, } \mathrm{P}=\text { floor. }\end{array}$} \\
\hline
\end{tabular}

Table 2 Surfaces by orientation, ceiling and floor; Models MC, BM1 and BM2, Mexicali, B.C.

Source: Elaboration from executive plans of the projects

The construction systems of the three housing models are shown in Table 3 , and the global heat transfer coefficients of each of them are included.

\begin{tabular}{|c|c|c|c|c|}
\hline & Ceiling & $\begin{array}{c}\mathbf{U} \\
\left(\mathbf{W} / \mathbf{m}^{2}\right. \\
\left.{ }^{\circ} \mathbf{C}\right)\end{array}$ & Walls & $\begin{array}{c}\mathbf{U} \\
\mathbf{W} / \mathbf{m}^{2} \\
{ }^{\circ} \mathbf{C}\end{array}$ \\
\hline $\mathrm{MC}$ & Vault joist & 0.345 & $\begin{array}{l}\text { Common concrete } \\
\text { block } 0.12 \mathrm{~m}\end{array}$ & 2.992 \\
\hline \multirow[t]{2}{*}{ MB1 } & \multirow[t]{2}{*}{$\begin{array}{l}\text { Wooden } \\
\text { structure }\end{array}$} & \multirow[t]{2}{*}{0.2506} & $\begin{array}{l}\text { Common concrete } \\
\text { block } 0.12 \mathrm{~m}\end{array}$ & 2.992 \\
\hline & & & $\begin{array}{l}\text { Common concrete } \\
\text { block } \\
0.12 \mathrm{~m} \text {, polystyrene } \\
\text { thermal insulation } \\
0.0254 \mathrm{~m}(1 \text { ") }\end{array}$ & 0.956 \\
\hline MB2 & $\begin{array}{l}\text { CCA-6 panels } \\
\text { thickness } 0.175 \\
\mathrm{~m}\end{array}$ & 0.5549 & $\begin{array}{l}\text { Block } 0.15 \times 0.40 \\
\text { x0.40 m, CCA-4 } \\
\text { type "O" and "U" }\end{array}$ & 0.8624 \\
\hline
\end{tabular}

Table 3 Construction systems and global heat transfer coefficient (U), case studies

Source: Elaboration from the CATEDI Program, Luna

All homes have a reinforced concrete floor $0.10 \mathrm{~m} \mathrm{f} ' \mathrm{c}=240 \mathrm{~kg} / \mathrm{cm}^{2}(\mathrm{U}=3.18 \mathrm{~W} /$ $\mathrm{m}^{2}{ }^{\circ} \mathrm{C}$ ); single glass windows and aluminum hoses $\left(\mathrm{U}=7.24 \mathrm{~W} / \mathrm{m}^{2}{ }^{\circ} \mathrm{C}\right)$; and drum type wooden doors $\left(\mathrm{U}=2.78 \mathrm{~W} / \mathrm{m}^{2}{ }^{\circ} \mathrm{C}\right)$.

The bioclimatic criteria of BM1 are: a) roof with a lightened wooden structure, exterior sheet and interior insulation, which functions as a double roof with ventilated attic; b) $0.12 \mathrm{~m}$ concrete block wall in north and south walls; plus thermal insulation $0.0254 \mathrm{~m}$ ( 1 ") in east and west walls; c) location of windows that promote cross ventilation; d) window shading elements with roof extension; e) use of light colors on exterior walls.

The bioclimatic techniques of the BM2 are: a) roof made of panels of autoclaved cellular concrete (CCA), type CCA-6; b) CCA walls, type CCA-4; c) use of natural ventilation and lighting; d) use of outdoor patios; e) use of solar protection on walls; f) interior heights greater than $2.40 \mathrm{~m}$.

For each case study, a base case was established, which is the one that matches the real home built. Modifications were proposed to the design of the housing envelope, to improve energy performance (Table 4). 


\begin{tabular}{|c|c|}
\hline Key & $\begin{array}{l}\text { Considerations } \\
\text { Business model (MC) }\end{array}$ \\
\hline $\begin{array}{l}\text { Base } \\
\text { case }\end{array}$ & $\begin{array}{l}\text { Joist and vault ceiling } 0.20 \mathrm{~m} \text {, concrete block wall } 0.12 \\
\mathrm{~m} \text {, windows without shade }\end{array}$ \\
\hline $\mathrm{A}$ & $\begin{array}{l}\text { Base case }+0.0254 \mathrm{~m}(1 \text { ") polystyrene thermal } \\
\text { insulation on south wall }\end{array}$ \\
\hline B & $\begin{array}{l}\text { Base case }+0.0254 \mathrm{~m}(1 \text { ”) polystyrene thermal } \\
\text { insulation on west wall }\end{array}$ \\
\hline $\mathrm{C}$ & $\begin{array}{l}\text { Base case }+0.0254 \mathrm{~m}(1 \text { ") polystyrene thermal } \\
\text { insulation on south and west walls }\end{array}$ \\
\hline $\mathrm{D}$ & $\begin{array}{l}\text { Base case }+0.0254 \mathrm{~m}(1 \text { ") polystyrene thermal } \\
\text { insulation on south, west and east walls. }\end{array}$ \\
\hline $\mathrm{E}$ & $\begin{array}{l}\text { Joist and vault ceiling } 0.20 \mathrm{~m}, \mathrm{CCA}-4 \text { autoclaved } \\
\text { cellular concrete block wall, }\end{array}$ \\
\hline \multicolumn{2}{|r|}{ Bioclimatic model 1 (BM1) } \\
\hline $\begin{array}{l}\text { Base } \\
\text { case }\end{array}$ & $\begin{array}{l}\text { Wooden roof with lateral ventilation on two sides and } \\
0.508 \mathrm{~m}(2 \text { ) polystyrene thermal insulation and } \\
\text { exterior covered with galvanized sheet. } 0.12 \mathrm{~m} \text { concrete } \\
\text { block walls in north and south orientation. } 0.12 \mathrm{~m} \\
\text { concrete block walls }+0.0254 \mathrm{~m}(1 \text { ") polystyrene } \\
\text { thermal insulation in east and west orientation. } \\
\text { Shadowless windows }\end{array}$ \\
\hline A & $\begin{array}{l}\text { Base case }+0.0254 \mathrm{~m}(1 \text { ”) polystyrene thermal } \\
\text { insulation on south wall }\end{array}$ \\
\hline $\mathrm{F}$ & $\begin{array}{l}\text { CCA- } 6 \text { autoclaved aerated concrete panel ceiling, } 0.17 \\
\text { m, CCA- } 4 \text { autoclaved aerated concrete block wall, } \\
\text { Shadeless windows }\end{array}$ \\
\hline G & $\begin{array}{l}\text { Joist and vault ceiling } 0.20 \text {, concrete block wall } 0.12 \text {, } \\
\text { windows without shade }\end{array}$ \\
\hline \multicolumn{2}{|r|}{ Bioclimatic model 2 (BM2) } \\
\hline $\begin{array}{l}\text { Base } \\
\text { case }\end{array}$ & $\begin{array}{l}\text { CCA- } 6 \text { autoclaved cellular concrete panel ceiling, CCA- } \\
4 \text { autoclaved cellular concrete block wall, windows } \\
\text { without shade }\end{array}$ \\
\hline $\mathrm{H}$ & $\begin{array}{l}\text { CCA-6 autoclaved cellular concrete panel ceiling, CCA- } \\
4 \text { autoclaved cellular concrete block wall, windows with } \\
\text { shade }\end{array}$ \\
\hline
\end{tabular}

Table 4 Study cases. Source: self made

The evaluation of the case studies was carried out with the NOM-ENER-2011 calculation tool prepared for the Secretary of Energy and the National Commission for the Efficient Use of Energy (Danish Energy Agency, 2017; CONUEE, 2017). Screens of the assessment tool are shown in Figure 3.

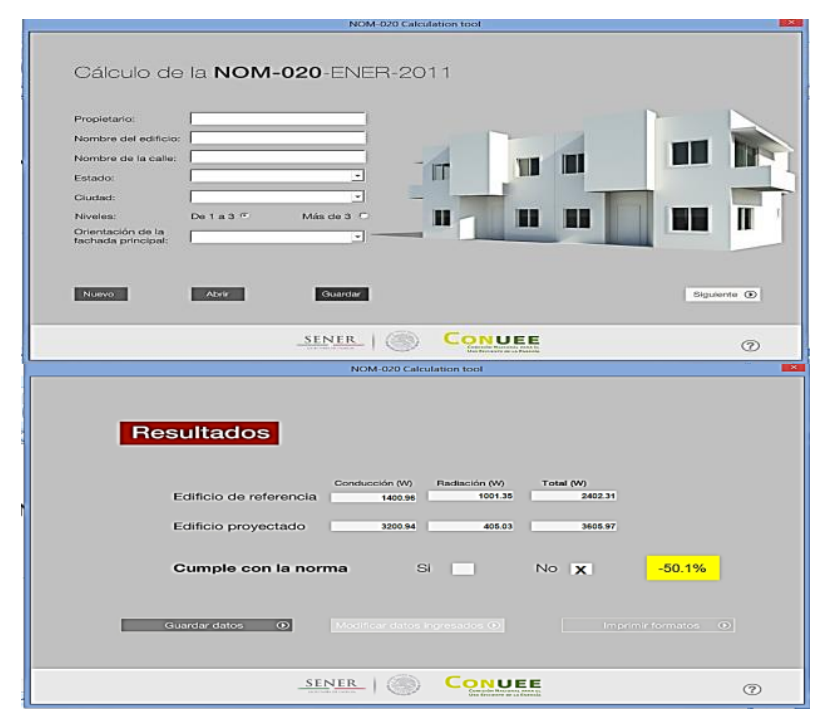

Figure 3 NOM-020-ENER- 2011 Calculation Tool, SENER-CONUEE

Source: https://www.gob.mx/conuee/acciones-yprogramas/herramienta-calculo-nom-020-ener-2001

\section{Results}

The results are presented by type of home, the base case and the modifications made to comply with NOM-020 are considered.

Table 5 shows the heat gain of the commercial model (joist and vault ceiling, and concrete block walls). It is observed that the MC, without insulation in ceilings and walls, has $50 \%$ more heat gain than the value allowed to approve compliance with NOM-020.

Thus, even when you have a joist and vault ceiling, it is not enough to achieve compliance with NOM-020, nor with the partial isolation of any of the orientations (south, west or east), isolation is required. of the 3 orientations mentioned (Case D) or the change for a construction system with a higher thermal resistance (Case E).



Table 5 Heat gain, Commercial model (MC), NOM-020ENER-2011, Mexicali

Source: Elaboration based on the application of NOM020

In the case of the bioclimatic housing demonstration model (BM1) built with a wooden roof (ventilated attic) and concrete block walls, according to Table 6 , it is observed that even when it has a roof with thermal resistance (thermal insulation of polystyrene $0.0508 \mathrm{~m}$ ) and east and east walls with thermal insulation of polystyrene $0.0254 \mathrm{~m}$ (1"), does not meet the approval of NOM-020. 


\begin{tabular}{|c|c|c|c|c|c|}
\hline $\begin{array}{l}\text { Housinin } \\
\mathrm{g} \text { model }\end{array}$ & Conduction & $\begin{array}{l}\text { Heat gain (W) } \\
\text { Radiation }\end{array}$ & Total & $\begin{array}{c}\mathrm{NO} \\
\text { Ye } \\
\text { or }\end{array}$ & $\begin{array}{l}\text { ompliance } \\
\text { Energy } \\
\text { Saving } \\
\text { (\%) }\end{array}$ \\
\hline Ref & 1557.98 & 1225.2 & 2783.13 & & \\
\hline $\begin{array}{l}\text { Projected } \\
\end{array}$ & tousing & & & & \\
\hline $\begin{array}{l}\text { Base } \\
\text { case }\end{array}$ & 2347.71 & 738.90 & 3086.61 & No & -10.9 \\
\hline $\mathrm{A}$ & 2026.02 & 738.90 & 2764.92 & $\mathrm{Si}$ & 0.70 \\
\hline & 1759.56 & 738.90 & 2498.46 & $\mathrm{Si}$ & 10.20 \\
\hline
\end{tabular}

Table 6 Heat gain, Bioclimatic Model (BM1), NOM020-ENER-2011, Mexicali

Source: Elaboration based on the application of NOM020

To comply with NOM-020, it is required that the south, east and west walls be insulated, which implies increasing the surfaces with thermal insulation or substituting construction systems with higher thermal resistance. Table 7 shows the application of NOM-020 in a bioclimatic house built with autoclaved cellular concrete system. This system did allow the approval of NOM-020.

\begin{tabular}{|c|c|c|c|c|c|}
\hline \multirow{2}{*}{$\begin{array}{l}\text { Housin } \\
\text { g model }\end{array}$} & \multicolumn{3}{|c|}{ Heat gain (W) } & \multicolumn{2}{|c|}{ NOM-020 compliance } \\
\hline & Conduction & Radiation & Total & $\begin{array}{c}\text { Yes } \\
\text { or no }\end{array}$ & $\begin{array}{c}\text { Energy } \\
\text { Saving } \\
(\%)\end{array}$ \\
\hline \multicolumn{6}{|c|}{ Reference housing } \\
\hline & 1610.97 & 1165.6 & 2777.52 & & \\
\hline \multicolumn{6}{|c|}{ Projected housing } \\
\hline $\begin{array}{l}\text { Base } \\
\text { case }\end{array}$ & 1817.99 & 756.80 & 2574.79 & $\mathrm{Si}$ & 7.3 \\
\hline
\end{tabular}

Table 7 Heat gain, Bioclimatic Model (BM2), NOM020-ENER-2011, Mexicali

Source: Elaboration based on the application of NOM020

In Graphic 1, the total heat gains of the reference and projected housing of each of the study cases are shown; and Table 8 shows the energy efficiency per square meter $\left(\mathrm{m}^{2}\right)$ of the case studies.



Symbols: MC-Ref $=$ Reference commercial-housing model; MC-Pro $=$ Projected commercial-housing model. BM1-Ref = Bioclimatic model 1 - reference house; BM1-Pro = Bioclimatic model 1 - projected house .; BM2-Ref = Bioclimatic model 2 - reference house; $\mathrm{BM} 2$-Pro = Bioclimatic model 2 - projected house

Graphic 1 Total heat gain (W) of the MC, BM1 and BM2 models, NOM-020-ENER-2011, Mexicali
The models built or homes projected showed that the MC had a heat gain of $3605 \mathrm{~W}$, the BM1 of $3086.61 \mathrm{~W}$ and the BM2 of $2574.79 \mathrm{~W}$; it is observed that the bias of the bioclimatic models is $16 \%$ and $29 \%$ lower than the commercial model.

\begin{tabular}{|c|c|c|c|c|c|}
\hline $\begin{array}{c}\text { Business } \\
\text { model } \\
\text { MC }\end{array}$ & $\begin{array}{c}\text { Housing }\left(\mathbf{W} / \mathbf{m}^{\mathbf{2}}\right) \\
\text { Bioclimatic } \\
\text { model } \\
\text { BM1 }\end{array}$ & $\begin{array}{c}\text { Bioclimatic } \\
\text { model BM2 }\end{array}$ \\
\hline Ref & Proj & Ref & Proj & Ref & Proj \\
\hline 63.22 & 94.89 & 73.24 & 81.23 & 63.13 & 58.52 \\
\hline \multicolumn{2}{|c|}{ Symbology: Ref = Reference, Proj = Projected } \\
\hline
\end{tabular}

Table 8 Energy efficiency per $\mathrm{m}^{2}$, case studies, Mexicali Source: Our elaboration

The above shows that the commercial construction system is the one with the highest heat gain, therefore it turns out to be the least efficient; a better thermal performance per $\mathrm{m}^{2}$ was shown by the construction systems of the bioclimatic models.

\section{Conclusions}

For the climatic conditions of Mexicali, it is concluded that:

- Current construction systems are not sufficient to comply with NOM-020, they represent $50 \%$ more heat gain than allowed by the standard.

- $\quad$ It is required to apply thermal insulation measures at least in 3 (south, east and west) of the 4 basic orientations, which implies additional investment costs to have a home that passes the conditions of the standard.

- $\quad$ The modifications made in 2016 are not yet sufficient to achieve energy savings and maintain conditions of thermal comfort, it is necessary to readjust the global heat transfer coefficients used as a reference in hot dry climates.

The digital evaluation tool of NOM-020ENER-2011 resulted in an accessible and relevant instrument for its application, significantly facilitating the evaluation of projects. 
NOM-020 analyzes the impact of heat gain on the enclosure, gives priority to the criterion of thermal resistance; it does not allow to include the effects of shaded or ventilated ceilings or walls and construction systems greater than 5 layers, although it does consider shading in windows.

Finally, it will be important to have public policy elements that favor the inclusion of bioclimatic design criteria, which allow better thermal performance of the housing envelope, as well as to reduce electrical consumption while maintaining conditions of thermal comfort for the population.

\section{Acknowledgment}

To the National Housing Council (CONAVI) and the National Council of Science and Technology (CONACYT), for financing the project "Thermal comfort and energy saving in low-income homes in hot regions of Mexico, part two CONAVI-01-20"; to the housing developer Grupo RUBA, for the support for the construction of bioclimatic houses; Termoaislantes de México (Xella Mexicana) and Hebel, for the donation of the CCA material; and the Autonomous University of Baja California.

\section{References}

Agencia Danesa de Energía, Low Carbon Architecture, Herramienta de Cálculo de la NOM-020-ENER-2011. www.gob.mx/conuee/acciones-yprogramas/herramienta-calculo-nom_020

Alianza Global para Edificios y Construcción, Agencia Internacional de Energía y Programa del Medio Ambiente de las Naciones Unidas. (2019). 2019 Informe global para edificios y construcción: Hacia un sector de construcción y edificios cero emisiones, eficiente y resiliente. Recuperado de https://www.unenvironment.org/resources/publi cation/2019-global-status-report-buildings-andconstruction-sector
Comisión de Normas de Construcción de California. (2019). 2019 Código de Energía de California, Título 24, Parte 6 Recuperado de https://www.energy.ca.gov/programs-andtopics/programs/building-energy-efficiencystandards

Comisión Nacional para el Uso Eficiente de la Energía y Secretaria de Energía, 2017. Guía rápida de cálculo NOM-020-ENER-2011, México.

Diario Oficial de la Federación (2001, 25 de abril). Norma Oficial Mexicana NOM-008ENER-2001, Eficiencia energética en edificaciones. -Envolvente de edificios para uso habitacional. Ciudad de México, México: Secretaria de Energía. Recuperado de https://www.gob.mx/cms/uploads/attachment/fi le/181648/NOM_008_ENER_2001.pdf

Diario Oficial de la Federación (2011, 9 de agosto). Norma Oficial Mexicana NOM-020ENER-2011, Eficiencia energética en edificaciones. -Envolvente de edificios para uso habitacional. Ciudad de México, México: Secretaria de Energía. Recuperado de dof.gob.mx/nota_detalle.php?codigo=5203931 $\&$ fecha $=09 / 08 / 2011$

Diario Oficial de la Federación (2016, 4 de octubre). Resolución por la que se modifican los valores de coeficiente global de transferencia de calor $(\mathrm{K})$ de la Table 1 , se agregan definiciones y se acota la verificación de la Norma Oficial Mexicana NOM-O20 ENER-2011, Ciudad de México, México: Secretaria de Energía. Recuperado de dof.gob.mx/nota_detalle.php?codigo $=5455514$ $\&$ fecha $=04 / 10 / 2016$

Instituto Nacional de Estadística y Geografía. (2016). Anuario estadístico y geográfico por entidad federativa 2016. Recuperado de https://www.scribd.com/document/378510549/ Anuario-Estadistico-y-Geografico-Por-Entidad2016

Luna, A. (2017). Programa CATEDI. México: Universidad Autónoma de Baja California. 
Ministerio de Fomento Secretaría de Estado de Infraestructuras, Transporte y Vivienda Secretaría General de Vivienda Dirección General de Arquitectura, Vivienda y Suelo. (2019). Código Técnico de la Edificación. Documento Básico HE Ahorro de Energía. Recuperado de https://www.codigotecnico.org/index.php/menu -ahorro-energia.html

Secretaria de Energía, Sector Eléctrico Nacional, https://www.gob.mx/sener/acciones$\mathrm{y}$ - programas/estadisticas-del-sector-electricoe-indicadores-de-cfe; 2017 [Recuperado 23.07.17].

Sociedad Americana de Ingenieros de Calefacción, Refrigeración y Aire Acondicionado (2018). ANSI/ASHRAE/IES Standard 90.2-2018 Diseño energéticamente eficiente de edificios residenciales de baja altura Recuperado de https://ashrae.iwrapper.com/ViewOnline/Standa rd_90.2-2018

Universidad Autónoma de Baja California, Universidad Autónoma de Baja California Sur, Universidad Autónoma de Yucatán, Universidad de Colima y Universidad de Sonora. (2013). Reporte Técnico Final "Confort térmico y ahorro de energía en la vivienda económica en México: regiones de clima cálido seco y húmedo" 2da. Etapa. México: Fondo CONAVI-CONACYT. 